\title{
The Effect of Lead Processing Works on the Lead, Cadmium and Mercury Contents of Fungi.
}

\section{Liukkonen-Lilja, $\mathrm{H}$.}

J. F. Bergmann Verlag

1983

Liukkonen-Lilja, H. et al. 1983. The Effect of Lead Processing Works on the Lead, Cadmium and Mercury Contents of Fungi. Zeitschrift für Lebensmitteluntersuchung und -Forschung 176: $120-123$

http://hdl.handle.net/1975/200

Downloaded from Helda, University of Helsinki institutional repository.

This is an electronic reprint of the original article.

This reprint may differ from the original in pagination and typographic detail.

Please cite the original version. 


\title{
The Effect of Lead Processing Works on the Lead, Cadmium and Mercury Contents of Fungi
}

\author{
Helena Liukkonen-Lilja ${ }^{1}$, Taina Kuusi ${ }^{1}$, Kari Laaksovirta ${ }^{2}$, Martin Lodenius ${ }^{3}$, and Sulo Piepponen ${ }^{1}$ \\ 1 Technical Research Centre of Finland, Food Research Laboratory, SF-02150 Espoo 15, Finland \\ 2 Department of General Botany, University of Helsinki, SF-00710 Helsinki 71, Finland \\ ${ }^{3}$ Department of Environmental Science, University of Helsinki, SF-00710 Helsinki 71, Finland
}

\section{Einfluß der Bleiverarbeitungs-Industrie auf den Blei-, Cadmium- und Quecksilbergehalt der Pilze}

Zusammenfassung. Aus dem südfinnischen Tikkurila, Standort von drei bleiverarbeitenden Metallhütten, wurden 117 Pilzproben auf Blei-, Cadmium- und Quecksilbergehalt analysiert. Der Bleigehalt der Pilze nahm mit wachsendem Abstand von der größten Metallhütte $\mathrm{ab}$, und zwar sowohl bei den mycorrhizatragenden (symbiontischen) Arten als auch bei den Humuszersetzern. Im Distanzbereich unter $300 \mathrm{~m}$ betrug der Mittelwert aus zehn Proben $89 \mathrm{mg} / \mathrm{kg}$ Trockensubstanz $(11-300 \mathrm{mg} / \mathrm{kg})$. Im Nahbereich $(<50 \mathrm{~m})$ der kleineren Metallhütte lag der Mittelwert aus sieben Proben bei $71 \mathrm{mg} / \mathrm{kg}(26-100 \mathrm{mg} / \mathrm{kg})$. Der Bleigehalt aller untersuchten mycorrhizatragenden Pilze in Tikkurila betrug im Mittel $22 \mathrm{mg} / \mathrm{kg}(<0,5-300 \mathrm{mg} / \mathrm{kg})$ und lag damit stark signifikant höher als in anderen Gebieten Finnlands. Für die Humuszersetzer war dieselbe Differenz signifikant oder beinahe signifikant. Beim Cadmiumgehalt wurde eine geringe Zunahme in der Nähe der größten Metallhütte beobachtet $(<0,2-$ $56 \mathrm{mg} / \mathrm{kg}$ Trockensubstanz), nicht hingegen beim Quecksilbergehalt $(0,1-3,6 \mathrm{mg} / \mathrm{kg}$ Trockensubstanz).

Summary. The investigation area was Tikkurila, southern Finland, where three lead-processing plants are located. 117 samples of fungi were analyzed for their lead, cadmium and mercury contents. The lead contents of both mycorrhizal and humus decomposer fungi increased with decreasing distance from the largest lead works. At a distance of less than $300 \mathrm{~m}$ the mean lead content of 10 samples was $89 \mathrm{mg} / \mathrm{kg}$ of dry weight (range $11-300 \mathrm{mg} / \mathrm{kg}$ ). Near the smaller lead works, distance $<50 \mathrm{~m}$, the mean lead content of 7 samples was $71 \mathrm{mg} / \mathrm{kg}$ (range $26-100 \mathrm{mg} / \mathrm{kg}$ ). The mean lead content of all mycorrhizal fungi $(22 \mathrm{mg} / \mathrm{kg}$, range $<0.5$ $300 \mathrm{mg} / \mathrm{kg}$ ) in Tikkurila was very significantly higher than at other locations in Finland. In the humus de- composers this difference was significant or nearly significant. A slight increase in the cadmium content was observed near the largest plant (range $<0.2-56 \mathrm{mg} / \mathrm{kg}$ dry matter). The mercury contents were at the background level (range $0.1-3.6 \mathrm{mg} / \mathrm{kg}$ dry matter).

\section{Introduction}

The study area is the area most polluted by the metal industry in Finland, and the most serious environmental problem in Tikkurila stems from the lead emissions from the lead works. Tikkurila is located in the city of Vantaa, approximately $20 \mathrm{~km}$ north of Helsinki (Fig. 1). It is one of the densely populated areas of Vantaa, the lead works A built in 1928 being located in its centre (Fig. 1). A second works B, of smaller capacity and an accumulator plant, $\mathrm{C}$, are located in a less densely populated industrial area of Tikkurila, in the immediate neighbourhood of roads with dense traffic (Fig. 1). Plant A is at a distance of more than $1,500 \mathrm{~m}$ from these big roads. In addition to blocks of flats there are many small detached houses with gardens in Tikkurila.

Clearly increased lead contents have been found in Tikkurila from deposition studies [1], snow samples [2] and soil samples [3]. The influence of plant $A$ reaches a distance of $3.6 \mathrm{~km}$, the most seriously polluted area being at a distance of approximately $500 \mathrm{~m}$. Lead pollution caused by motor traffic has been insignificant compared with that caused by the industry. Investigations of the lead contents of cultivated edible plants in the area have shown very much higher values than in other locations $[2,4-6]$. For instance, in leafy vegetables at a distance of less than $300 \mathrm{~m}$ from plant $\mathrm{A}$, the lead content was $2-13 \mathrm{mg} / \mathrm{kg}$ fresh weight [6]. The cadmium and mercury contents of the soil and vegetables in Tikkurila were not clearly increased $[4,6]$. 


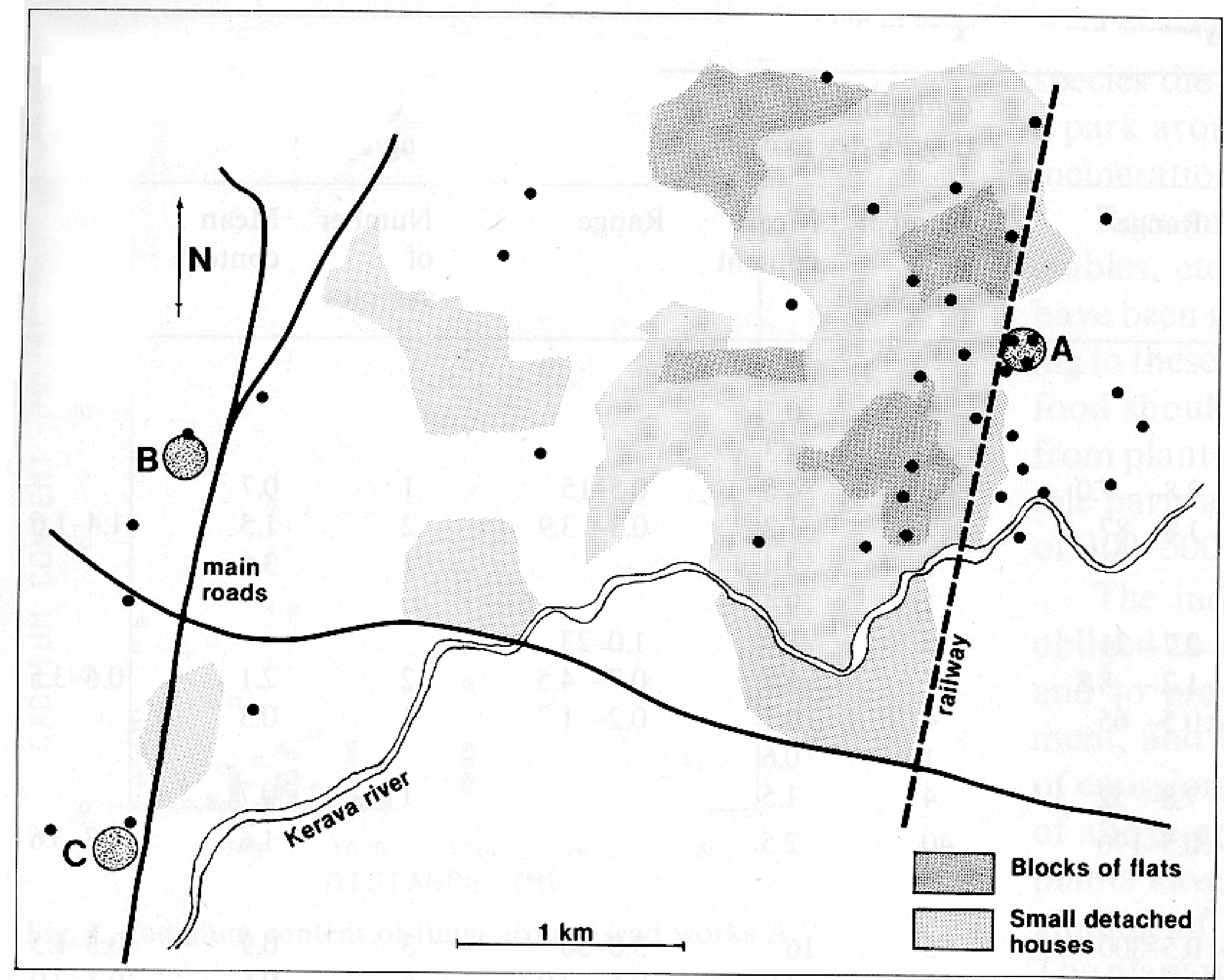

Fig. 1. Research area in

Tikkurila. $-\bullet=$ sampling sites, $A$ and $B=$ lead works, $C=$ accumulator plant
Only a few scattered data are available [4] concerning the heavy metal contents in the fungi of the area.

The purpose of the present investigation was to study the effect of lead-processing works on the heavymetal contents of fungi in Tikkurila. This study is part of a broader investigation into the lead, cadmium and mercury contents of fungi from several locations in Finland [7-9].

\section{Material and Methods}

Altogether 117 samples of fungi were collected in 1980-1981 from various locations in Tikkurila, most of them originating from the surroundings of plant A. Seventy-five samples were taken from a distance of less than $1,500 \mathrm{~m}$ and 13 samples at a distance of more than $1,500 \mathrm{~m}$ from the plant (Fig. 1). The samples were from different quarters, mostly from the most densely populated areas to the north, west and south of the plant. Twenty-nine samples were collected from the surroundings of the lead works B and accumulator plant $C$. The bulk of the fungi were mycorrhizal symbionts of trees, representing 27 species and 74 samples. Thirteen species and 40 samples of humus decomposers and one species and three samples of wood decomposers were included.

Before analysis the samples were cleaned, dried and homogenized. Lead and cadmium were assayed after wet combustion and extraction as a chelate using the flame technique of atomic-absorption spectrophotometry. Mercury was analysed by cold-vapour atomicabsorption spectrometry [9]. The mercury contents were measured only for samples picked at a distance of less than $600 \mathrm{~m}$ from plant A.

\section{Results and Discussion}

The lead, cadmium and mercury contents of all samples from Tikkurila are given in Table 1. The mean values for lead are clearly higher in Tikkurila than in
Helsinki for the same species [9], as shown in Table 2. This difference is greater in the mycorrhizal symbionts than in the humus decomposers. The cadmium and mercury contents of the same species in Tikkurila are at the same level as in Helsinki. The mean lead content in mycorrhizal symbionts in Tikkurila is nearly ten times greater and in humus decomposers approximately three times greater than the values in Helsinki. The lead contents of some species in Tikkurila are approximately two times greater than those obtained for fungi in Germany collected from unpolluted rural areas [10]. The mean values for cadmium in Tikkurila do not differ significantly from those in other areas, although the value for the humus decomposers is lowest and that for the mycorrhizal symbionts highest for the different areas (Table 2). The mercury values in Tikkurila are at approximately the same level as those in the control areas of the earlier study (Table 2).

The lead contents of 88 samples increase sharply with decreasing distance from plant A (Fig. 2). Thus, in 10 samples at a distance of less than $300 \mathrm{~m}$ the mean lead content is $89 \mathrm{mg} / \mathrm{kg}$ dry weight (range $11-300 \mathrm{mg} /$ $\mathrm{kg}$ ). The lead content in Lactarius necator (14 samples) and in Boletaceae (12 samples, B. edulis excluded) is clearly dependent on the distance. The amount of cadmium also increased with decreasing distance from plant $\mathrm{A}$, but the increase is less distinct than that of the lead content (Fig. 3 ).

In Finland the highest permitted lead content in fresh foods, fungi included, is $1 \mathrm{mg} / \mathrm{kg}$ fresh weight [11], which corresponds to approximately $12 \mathrm{mg} / \mathrm{kg}$ dry weight [9]. This value is reached at a distance of ap- 
Table 1. Lead, cadmium and mercury contents of the various fungus species in Tikkurila

\begin{tabular}{|c|c|c|c|c|c|c|c|c|c|}
\hline \multirow[t]{2}{*}{ Species } & \multicolumn{3}{|c|}{$\begin{array}{l}\text { Lead } \\
\text { (mg/kg dry matter) }\end{array}$} & \multicolumn{3}{|c|}{$\begin{array}{l}\text { Cadmium } \\
\text { (mg/kg dry matter) }\end{array}$} & \multicolumn{3}{|c|}{$\begin{array}{l}\text { Mercury } \\
\text { (mg/kg dry matter) }\end{array}$} \\
\hline & $\begin{array}{l}\text { Number } \\
\text { of } \\
\text { samples }\end{array}$ & $\begin{array}{l}\text { Mean } \\
\text { content }\end{array}$ & Range & $\begin{array}{l}\text { Number } \\
\text { of } \\
\text { samples }\end{array}$ & $\begin{array}{l}\text { Mean } \\
\text { content }\end{array}$ & Range & $\begin{array}{l}\text { Number } \\
\text { of } \\
\text { samples }\end{array}$ & $\begin{array}{l}\text { Mean } \\
\text { content }\end{array}$ & Range \\
\hline \multicolumn{10}{|l|}{ Humus decomposers } \\
\hline Hygrophorus pratensis & 1 & 6.0 & & 1 & 0.7 & & & & \\
\hline Laccaria laccata & 1 & 100 & & 1 & 4.3 & & & & \\
\hline Lyophyllum connatum & 4 & 4.9 & $3.8-7.0$ & 4 & 4.5 & $0.5-15$ & 1 & 0.7 & \\
\hline Marasmius oreades & 9 & 17 & $1.8-87$ & 9 & 1.2 & $0.3-3.9$ & 2 & 1.5 & $1.4-1.6$ \\
\hline Macrolepiota procera & 1 & 170 & & 1 & 2.4 & & 1 & 3.6 & \\
\hline Phaeolepiota aurea & 1 & 0.6 & & 1 & 9.4 & & & & \\
\hline Agaricus spp. & 3 & 13 & $2.7-21$ & 3 & 8.4 & $1.0-23$ & & & \\
\hline Coprinus comatus & 11 & 3.7 & $1.2-8.8$ & 11 & 1.8 & $0.7-4.5$ & 2 & 2.1 & $0.6-3.5$ \\
\hline Coprinus atramentarius & 4 & 17 & $<0.5-65$ & 4 & 0.7 & $0.2-1.8$ & 1 & 0.3 & \\
\hline Coprinus micaceus & 1 & 5.8 & & 1 & 0.6 & & & & \\
\hline Gasteromycetes & 4 & 32 & $7.8-52$ & 4 & 1.5 & $0.7-2.8$ & 1 & 0.7 & \\
\hline All species & 40 & 18 & $<0.5-170$ & 40 & 2.5 & $0.2-23$ & 8 & 1.6 & $0.3-3.6$ \\
\hline \multicolumn{10}{|l|}{ Mycorrhizal fungi } \\
\hline Boletus edulis & 5 & 63 & $<0.5-300$ & 5 & 16 & $3.0-56$ & 3 & 0.9 & $0.3-1.5$ \\
\hline Other Boletaceae & 15 & 24 & $<0.5-160$ & 15 & 3.0 & $0.5-7.9$ & 6 & 0.6 & $0.1-2.0$ \\
\hline Tricholoma columbetta & 1 & 18 & & 1 & 0.7 & & 1 & 0.4 & \\
\hline Amanita muscaria & 4 & 15 & $1.9-27$ & 4 & 18 & $12-25$ & 1 & 0.5 & \\
\hline Hebeloma crustuliniforme & 4 & 24 & $1.9-72$ & 4 & 1.9 & $0.4-4.3$ & & & \\
\hline Russula spp. & 16 & 17 & $2.5-180$ & 16 & 1.9 & $<0.2-5.6$ & 2 & 0.1 & $<0.1-0.2$ \\
\hline Lactarius necator & 16 & 20 & $0.9-46$ & 16 & 0.6 & $<0.2-2.4$ & 7 & 0.1 & $<0.1-0.2$ \\
\hline Other Lactarius spp. & 13 & 16 & $2.1-72$ & 13 & 1.3 & $0.2-2.8$ & 1 & 0.1 & \\
\hline All species & 74 & 22 & $<0.5-300$ & 74 & 3.5 & $<0.2-56$ & 21 & 0.4 & $<0.1-2.0$ \\
\hline \multicolumn{10}{|l|}{ Wood decomposers } \\
\hline Armillariella mellea & 3 & 2.3 & $<0.5-5.2$ & 3 & 4.3 & $4.0-0.8$ & 1 & 0.1 & \\
\hline All species & 117 & & $<0.5-300$ & 117 & & $<0.2-56$ & 30 & & $<0.1-3.6$ \\
\hline
\end{tabular}

Table 2. Comparison of lead, cadmium and mercury contents of fungi in Tikkurila with those of other locations in Finland $[8,9]$

\begin{tabular}{|c|c|c|c|c|c|c|}
\hline \multirow[t]{2}{*}{$\begin{array}{l}\text { Place of } \\
\text { collection }\end{array}$} & \multicolumn{2}{|c|}{$\begin{array}{l}\mathrm{Pb}(\mathrm{mg} / \mathrm{kg} \text { dry } \\
\text { matter) }\end{array}$} & \multicolumn{2}{|c|}{$\begin{array}{l}\mathrm{Cd}(\mathrm{mg} / \mathrm{kg} \text { dry } \\
\text { matter) }\end{array}$} & \multicolumn{2}{|c|}{$\begin{array}{l}\mathrm{Hg}(\mathrm{mg} / \mathrm{kg} \text { dry } \\
\text { matter) }\end{array}$} \\
\hline & $\begin{array}{l}\text { Num- } \\
\text { ber of } \\
\text { sam- } \\
\text { ples }\end{array}$ & $\begin{array}{l}\text { Mean } \\
\text { con- } \\
\text { tent }\end{array}$ & $\begin{array}{l}\text { Num- } \\
\text { ber of } \\
\text { sam- } \\
\text { ples }\end{array}$ & $\begin{array}{l}\text { Mean } \\
\text { con- } \\
\text { tent }\end{array}$ & $\begin{array}{l}\text { Num- } \\
\text { ber of } \\
\text { sam- } \\
\text { ples }\end{array}$ & $\begin{array}{l}\text { Mean } \\
\text { con- } \\
\text { tent }\end{array}$ \\
\hline \multicolumn{7}{|c|}{$\begin{array}{l}\text { Humus } \\
\text { decomposers }\end{array}$} \\
\hline Tikkurila & 40 & 18 & 40 & 2.5 & 8 & 1.6 \\
\hline Helsinki & 178 & 6.3 & 178 & 5.3 & 192 & 6.5 \\
\hline Mikkeli & 32 & 4.3 & 33 & 16 & 39 & 6.3 \\
\hline $\begin{array}{l}\text { Control } \\
\text { area }\end{array}$ & 18 & 3.0 & 18 & 2.8 & 23 & 1.7 \\
\hline \multicolumn{7}{|c|}{$\begin{array}{l}\text { Mycorrhizal } \\
\text { fungi }\end{array}$} \\
\hline Tikkurila & 74 & 22 & 74 & 3.5 & 21 & 0.4 \\
\hline Helsinki & 50 & 2.7 & 50 & 2.7 & 49 & 0.7 \\
\hline Mikkeli & 9 & 1.0 & 9 & 0.7 & 17 & 1.1 \\
\hline $\begin{array}{l}\text { Control } \\
\text { area }\end{array}$ & 58 & 1.4 & 58 & 0.9 & 76 & 0.2 \\
\hline
\end{tabular}



Fig. 2. Lead content of fungi around lead works A 


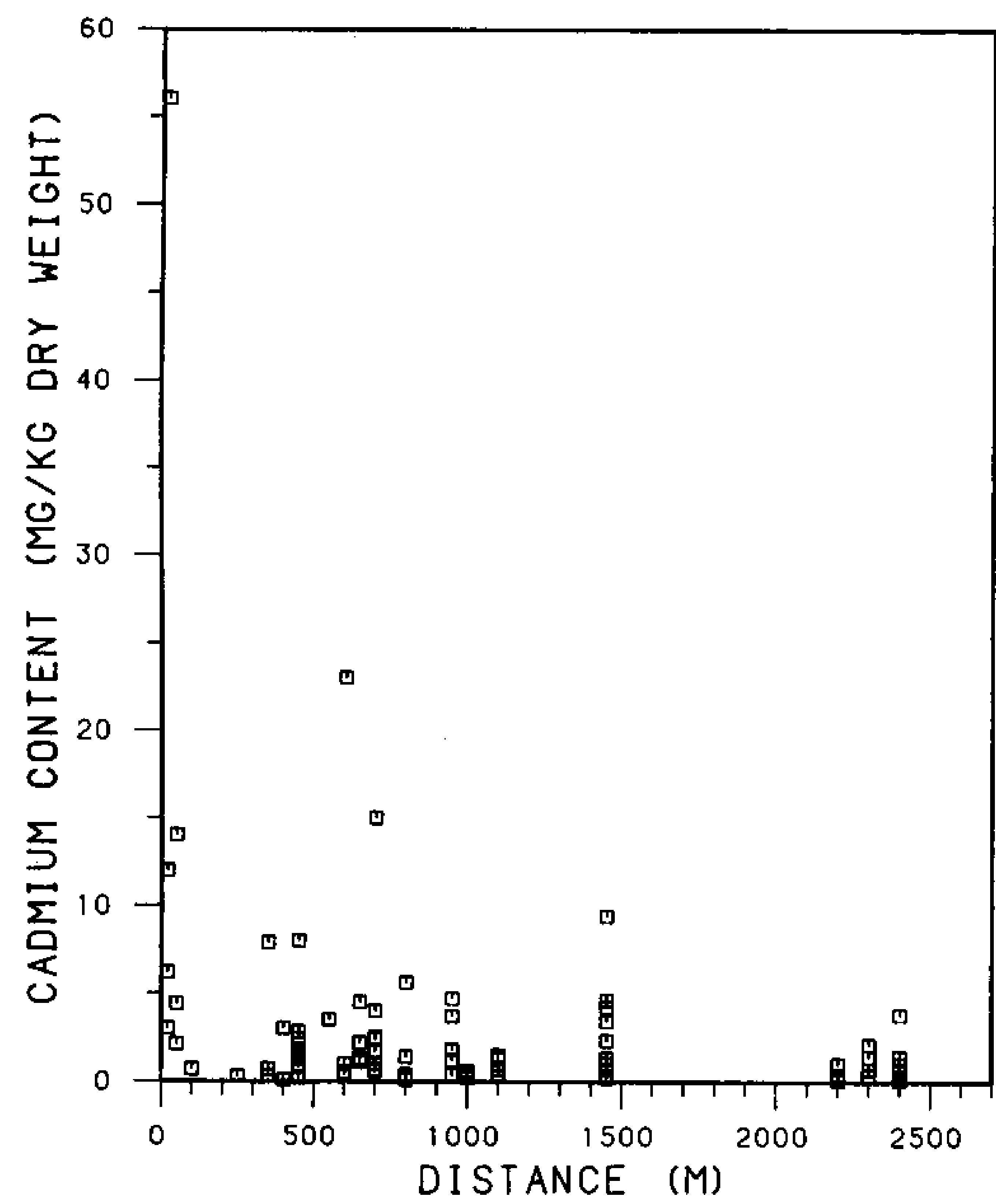

Fig. 3. Cadmium content of fungi around lead works A

proximately $900 \mathrm{~m}$, which means that up to this point the values are on average higher than the permitted limit. In all samples at a distance of less than $300 \mathrm{~m}$, the lead content is $1 \mathrm{mg} / \mathrm{kg}$ fresh weight or more. Even at a distance of $1,450 \mathrm{~m}$ two of the samples have a value higher than the limit. When the distance is more than $2,000 \mathrm{~m}$ (13 samples), the lead content is the same as in Helsinki.

In the immediate neighbourhood of the smaller plant B (distance less than $50 \mathrm{~m}$ ) the mean lead content in 7 samples was $71 \mathrm{mg} / \mathrm{kg}$ dry matter (range 26$100 \mathrm{mg} / \mathrm{kg}$ ), which corresponds to the mean of fungi at a distance of $400 \mathrm{~m}$ from plant $\mathrm{A}$ (13 samples). At a distance of approximately $500 \mathrm{~m}$ from $\mathrm{B}$ the mean lead content was $11 \mathrm{mg} / \mathrm{kg}$ dry matter (range $2.3-32 \mathrm{mg}$ / $\mathrm{kg}$ ); in this case, the close vicinity of the main roads may increase the values.

Only few investigations are available concerning the influence of the lead-processing industry on the heavy metal content of fungi. The results of a limited study concerning the lead content of fungi in the neighbourhood of a lead smelter [12] correspond to the present lead values from Tikkurila. Elevated lead and mercury contents in Lycoperdon perlatum have been found near a refuse-incineration plant [13], and in Agaricus species the highest lead and cadmium contents were in a park around a road with dense traffic and a rubbishincineration plant in the immediate vicinity [14].

Recommendations to limit the growing of vegetables, etc. in the neighbourhood of the lead works have been given in Tikkurila in 1981 and 1982. According to these recommendations, no plants used as human food should be grown at a distance of less than $300 \mathrm{~m}$ from plant $A$, and no leafy vegetables or plants with edible parts above ground should be grown at a distance of $300-500 \mathrm{~m}$.

The industrial enterprises in Tikkurila have been obliged to improve the treatment of smoke emissions and to prevent the spreading of dust in the environment, and these measures have decreased the amount of emission. This has already lessened the lead content of above-ground vegetables. The lead emissions of the plants have decreased from 50 tons per year in the beginning of the 1970s to 1-2 tons per year at present. The plant with the highest capacity will be moved away from its present location in the near future.

Acknowledgements. This investigation was supported by a grant from the Academy of Finland.

\section{References}

1. Laamanen A, Ryhänen A (1971) Suomen Kemistilehti 44B:367

2. Lakanen E, Erviö R (1971) Ann Agr Fenn 10:114

3. Erviö R, Lakanen E (1973) Ann Agr Fenn 12:200

4. Hårdh JE (1977) J Sci Agric Soc Fin 49:209

5. Erviö R (1977) Ann Agr Fenn 16:172

6. Myöhänen $P$ (1981) Vantaan kaupungin ympäristölautakunta, Report, tammikuu $9 \mathrm{pp}$

7. Lodenius M, Herranen M (1981) Chemosphere 10:313

8. Lodenius M, Kuusi T, Laaksovirta K, Liukkonen-Lilja H, Piepponen S (1981) Ann Bot Fenn 18:183

9. Kuusi T, Laaksovirta K, Liukkonen-Lilja H, Lodenius M, Piepponen S (1981) Z Lebensm Unters Forsch 173:261

10. Seeger R, Meyer E, Schönhut S (1976) Z Lebensm Unters Forsch $162: 7$

11. Anonym (1979) Elintarvikkeiden sisältämät vieraat aineet. Elinkeinohallituksen päätös $3050 / 51 / 79$

12. Enke M, Matschiner H, Achtzen MK (1977) Nahrung 21:331

13. Quinche JP (1979) Bull Romand Mycol n:o 10:13

14. Quinche JP (1980) Bull Mycol n:o 2:20

Received September 28, 1982 